\title{
Including Pervasive Skills in an Accounting Curriculum at a Rural South African University
}

\section{Mark Livingstone Sam Lubbe}

\begin{abstract}
Accounting programs at South African universities strive to attain and maintain accreditation with the South African Institute of Chartered Accountants (SAICA), an important component of which is incorporating pervasive skills into the curriculum. This paper details how a methodology was identified and adopted in order to incorporate these requirements across the four years of a yet to be accredited professional undergraduate accounting degree. The process commenced by mapping program objectives to individual modules thus facilitating a mapping and scaffolding process of the program. Focus group interviews with discipline leaders resulted in a coherent and coordinated approach to curriculum review which included consideration of the specific needs of students attending a rurally based South African University. The concept of a capstone course was integrated into the final year of the program in order to compliment and complete concepts encountered earlier. Future studies subsequent to the adoption of this methodology may develop or evaluate its efficacy.
\end{abstract}

Keywords: Capstone course, SAICA, Mapping, scaffolding, pervasive skills, attributes 


\section{Introduction}

Departments of Accounting at South African Universities strive to attain and maintain accreditation of their academic programs by the South African Institute of Chartered Accountants (SAICA). Van der Schyf (2008) pointed out that 'the status of these departments is dependent upon their accreditation status'. An integral part of the accreditation process is compliance with the Competency Framework issued by SAICA. This framework originally issued in 2008 and revised as recently as 2014. SAICA (2014) identifies a group of pervasive competencies that must be integrated into the accounting program. The framework identifies three categories of pervasive skills, ethical behaviour and professionalism, personal attributes and professional skills which must all be integrated into the academic program which SAICA expect will improve students' ability to master the technical requirements included in the document.

The aim of this study was to test the appropriateness of the whole-ofprogram methodology for the inclusion of pervasive skills in the accounting curriculum at Rural South African Universities.

The paper details the process followed by a rurally based South African university to integrate these skills into the four years of a yet to be accredited SAICA professional undergraduate accounting degree. The sections that follow will discuss how other institutions have revised their offerings to include pervasive skills, followed by the methodology adopted for the project and its findings. It will conclude with recommendations and ideas for future research.

\section{Literature Review}

\section{What are Pervasive Skills?}

Accounting educationalists from Zeff in 1979 through to Power 1990 recognized accounting syllabi were becoming swamped in theory at the expense of critical and reflective skills. These critical and reflective skills were the initial stages of the fifteen synonymous terms, (core, key, essential, nontechnical, employability, soft, transferrable, capabilities, general, competencies, graduate attributes, enterprise, pervasive, outcomes and skills) identified by Bunney, Sharplin and Howitt in 2015 describing the qualities expected in an accounting graduate entering professional employment. Throughout the nineties and the early part of the second millennia much was written about 
integrating these qualities or graduate attributes in individual modules (Ashbaugh, Johnstone \& Warfield 2002; English, Bonanno, Ihnatko, Webb \& Jones 1999; Boyce 2001) whilst very little was done with regard to integrating them throughout an entire curriculum (Willcoxson, Wynder \& Laing 2010).

Despite pronouncements internationally that these attributes should be integrated rather than taught separately (International Accounting Education Board (3), 2004) by 2008 Willcoxson, Wynder and Laing could only find two articles, one in accounting and the other in education, which dealt the development of professional skills in across an entire university program.

\section{Why there is a Need for Pervasive Skills in Accounting Graduates}

Various stake holders have contributed to the advancement of the pervasive skills agenda across various disciplines and countries. The Bedford Committee on Future Accounting Education commissioned by the American Accounting Association in 1986 paved the way for the AICPA (American Institute of Certified Public Accountants) to release their Initial Core Competency Framework in 1999. The 2011 revision of this framework identified three categories: functional competencies, personal competencies and broad business perspective (AICPA 2011). Similar developments from governments in the United Kingdom (the Dearling Report - NCIHE 1997), Australia (the Mathews Report: Mathews, Jackson \& Brown, 1990) and in South Africa, the professional society SAICA, released its initial competency framework in 2006 (SAICA 2006).

During 2012 the International Accounting Education Standards Board (IAESB) revised its International Education Standard 3 (IES 3) highlighting the relationship fostered between the accounting profession and providers of accounting education programmes. This standard aims to prescribe the mix of pervasive skills that aspiring professional accountants should have (IFAC, IES $3)$. These endeavours aim at reducing the gap between what accounting and business practitioners expect (Jackling \& De Lange 2006), quality authorities legislate and universities attempt to provide and constitutes what is colloquially referred to generic, soft and pervasive skills in business circles and graduate attributes in academia.

In a survey of finance modules at universities throughout the UK 41 of the 197 skills identified in the course literature was soft skills (Lakshmi 2013) 
and they conclude that finance education lags behind what is required in the real world. Australian researchers from Deakin and Victoria Universities recognize that although emphasis is being placed on developing Graduate Employability Indicators more work needs to be done from a curriculum perspective in order to integrate them more effectively (Naidoo, Jackling, Oliver \& Prokofieva 2012). The next part of the paper will identify the processes adopted during the updating processes and will examine how best to address South African rural circumstances.

\section{What are the Specific Needs of the Students Attending a Rural Tertiary Institution?}

In answering what the specific needs of a student at a rural South African university are the Teaching and Learning Strategy of the University of Zululand provides the following guidance '....mastery of spoken English may, as at other universities, mask serious deficiencies in reading and writing'. It continues to emphasize:

The teaching and learning strategy must take the background of the students into consideration, and must allow for the needs of students who lack adequate preparation for university studies. The majority of students come from poor families and additional financial challenges, so it is imperative that any remedial action takes place within the context of a normal programme of study. The teaching and learning strategy must take the background of the students into consideration, and must allow for the needs of students who lack adequate preparation for university studies. The majority of students come from poor families and additional financial challenges, so it is imperative that any remedial action takes place within the context of a normal programme of study.

From a South African academic perspective it has been suggested that there should be a move away from 'service courses' for accounting to a form that integrates subject and language specialists in a team teaching environment (Koch \& Kriel 2005). They identify that the problem may be an undeveloped discipline-based cognitive and conceptual framework and suggest that the problem may not be reading or English, but conceptualization concluding that these skills should be developed through mainstream teaching. 


\section{How Students' Needs can be Integrated into a Curriculum}

In an apparent oversight the Willcoxson paper omitted reference to Robley Whittle and Murdoch-Eaton (2005; 2006) who proposed a mapping methodology used in a medical program at Leeds University in England. Rather than adopting a 'bolt on' solution (Dunne; 1995) they used project based course components to integrate the skills into approximately one third of the undergraduate medical curriculum. They chose this method, student selected components with an embedded approach (Chapple \& Tolley; 2000 and Fallows \& Steven, 2000), to impart the skills appropriate of a medical professional as there was a perception that alteration of a core module may develop these skills out of context.

In an effort to understand curriculum mapping they trace its origins from school level (English 1978) until its recent use by Harden in 2001 which aims at matching declared aims with what is taught and learned. By adding a fourth dimension, assessment, an alignment loop created which enabled them to map the four dimensions by:

Declared - from curriculum documentation

Taught - student feedback forms

Delivered - per supervisor project feedback

Assessed - per documents mapped to 1,2 and learned.

From an American perspective Herring and Williams (2000) argue that curriculum change in accounting is hampered by the 'discipline specific orientation' of accounting faculty who has had very little training in teaching or educational research. They used 7 competencies identified by Deppe, Sonderegger, Stice, Clark and Streuling in 1991 to prepare a Curriculum objectives hierarchy which emphasizes assessment to obtain program goals. These program goals inform discipline objectives which are subsequently incorporated into individual course objectives. They argue that a syllabus which is structured on textbook or discipline principles should be transformed into one which is derived from objectives. This competency based format requires faculty to decide on its program based goals cascading downwards to curriculum and course objectives. They do however stress that:

- This plan must be formulated with the specific needs of their students in mind. 
- All staff must buy into the objectives based curriculum methodology.

- Faculty must lead the other willing (students, external based constituents and administrators) to move on from a subject based approach to teaching.

- A 'curriculum and assessment committee' should drive the process by setting and reviewing program goals and curriculum objectives which are evaluated regularly with those findings reported on at regular intervals.

Staff at the University of the Sunshine Coast (Willcoxon, Wynder \& Laing, 2008) presented a methodology for developing professional competencies and graduate attributes throughout a program, the whole-ofprogram approach, rather than relying on individual courses for pervasive skills development. They undertook a mapping process to ensure program and course objectives were linked to professional and institutional graduate attributes. Their process can be summarised as follows:

- Map the courses taught on the programme

- Develop a programme map (objectives, teaching and assessment)

- Analyse the depth to which pervasive skills are being taught

- Review the teaching of all academic staff on the programme

- Consider changes in course objectives, teaching activities and teaching methods

Bunney and Therry (Australia) conducted a longitudinal study, resulting in a series of three articles published in 2010, 2013 and 2015 which initially examined the extent to which the twelve core courses in a post graduate program incorporated 'employability skills' (Bunney \& Therry 2010). The findings indicated that initially the program was unstructured, lacked coordination and needed the services of a learning advisor. The role of the learning advisor, recommended in the concluding remarks and overview would be to ensure regular meetings of the course coordinators during which time their professional attributes would be developed in areas of strategy, assessment and feedback whist allowing staff to exchange ideas.

The first phase of the project involved four phases which included

- Identifying the employability skills 
- Determining the extent to which they were being addressed (by examining unit plans, questionnaires and interviews with coordinators)

- Developing an 'Employability Skills Checklist'

- Developing a framework to embed (map and scaffold) the skills identified coherently and cohesively

The 2013 article emphasizes that a 'whole-of-program' strategy for embedding skills across the curriculum is critical if the reviewing process is to be effective. The role of the learning advisor was expanded to include a 2-year period during which the advisor was attached to 3 modules for each of the four semesters. Whilst the project was on-going and its effects yet to be evaluated it was envisaged that the advisor would deliver lectures and tutorials and assist the unit coordinators integrate non-technical skills into assessment activities. Although each coordinator is only allocated a six month crash course in implementing employability skills the supplementary workshops and support activities would help the initiative bear fruit.

The final part of the series published in 2015, proved, at least initially, that the program was allocated sufficient resources to absorb and mentor new staff members. This resource allocation must be sustained for the long term. The paper articulates the three phases (development, implementation and evaluation) concluding with the findings of a triangulated evaluation (students, staff and unit plans). It emphasizes that in addition to the approach being effective, small group sessions, particularly with international students (nonEnglish first language speakers), increases the effectiveness of teaching employability skills.

\section{What is Being Done in South Africa?}

Recent research conducted in South Africa by Barac and du Plessis (2014) suggests that the heads of accounting disciplines at SAICA accredited universities '...perceive the acquisition of some pervasive skills to be best achieved in the real-world, practical workplace, rather than in the theoretical confines of the universities' lectures and tutorials'. This finding is significant as the SAICA-CF is clear that all competencies outlined are expected at entry into the workplace. Furthermore, Strauss-Keevy (2014), also a South African based researcher, agreed finding that accounting academics at these institutions 
are also unaware of their responsibility with respect to imparting all the pervasive competencies during the education program.

The challenges issued in these recent South African papers are:

1. integrate ethics into the major courses (Barac \& du Plessis 2014);

2. reduce reliance on the traditional approach of assignments, examinations and tests to skills and attributes could be developed and assessed through group work, group projects and simulations (Barac \& du Plessis 2014);

3. introduce a research component thus improving graduate's ability to communicate effectively using academic, business or appropriate discourse (Barac \& du Plessis 2014); and

4. 'accept(ing) that the responsibility rests with them and that they should develop innovative methods to develop these skills' (Strauss-Keevy 2014).

\section{South Africa and Curricula Development}

Accounting departments adapt the externally prepared SAICA-CF as the curriculum segregating teachers from curriculum developers in a situation not dissimilar to that which prevailed at the Technikons in South Africa. Bester and Schultz (2012) compared two approaches in an effort to determine the most appropriate way to curriculum review and redesign. They concluded that using a mapping process for this purpose was better than a template which focused on constructive alignment and cognitive complexity.

This template is similar to the assessment loop philosophy articulated by Robley Whittle and Murdoch (2013). Outcomes included in course materials were traced through teaching activities to assessment criteria and finally the assessment activities

Teaching-Learning activities are placed at the centre of Harden's (2001) mapping model which links outcomes, subject content and assessment tasks. The mapping process is a reliable process (Madiba 2011) which enables lecturers to reflect on processes encouraging participation from students through their success and professional development. Bester and Schultz (2012) go on to point out lecturer participation in the mapping process encourages 
reflection on your own teaching and facilitates change in their perception of their role in the curriculum design process.

\section{Capstone Courses and Pervasive Skills Development}

Internationally capstone courses are used during the terminal phases of a program to bring together concepts previously taught in specific disciplines. The University of Cape Town's (Maughan 2013) developed a capstone course aimed at ensuring the requirements of the 'competency framework' were met. They followed a process involving mapping the course offerings to the framework in order to establish compliance levels. Once gaps had been identified they decided to incorporate a number of finance topics with pervasive skills in an effort to present a course aimed at preparing students to write the APC which emphasizes professional competency (research and analysing complex business scenarios skills) rather than technical ability. Student evaluations were positive and included a number of suggested improvements notwithstanding the concluding remarks that the literature would help in improving the offering.

\section{The Importance of Assessment and Quality Assurance in the Review Process \\ Research Methodology}

The data was assimilated through a questionnaire which was consolidated into a table which was circulated to academics responsible for individual modules within the core accounting component of the program. The evidence was then triangulated through e-mails, semi structured interviews, document scrutiny and focus groups. No additional efforts to increase validity or objectivity were undertaken which is in sharp contrast to Robley, Whittle and Murdoch-Eaton (2005) who used the services of a research assistant with no curricular development or teaching responsibility to collect and analyse the data.

Although a variety of different data collection methods were used the study is a qualitative interpretevist analysis that posits that the whole-of program approach may be a suitable method of curriculum update for adoption by rural South African universities. 


\section{Questionnaires}

A questionnaire requested each lecturer to detail how, if at all, each component of the twenty-eight competencies was addressed or assessed in the module(s) for which they were responsible. In all 26 modules (of 32 in the program) over four years are taught by the 14 academics in the department all of whom responded to the questionnaire. The remaining 6 modules are spread between Economics (2); Law (2); and Maths and Stats (2); the latter of which is housed in a separate faculty.

The consolidate program map was returned to all academics who were charged with ensuring accuracy of the final document. Those requesting changes to the matrix were included in selection for the semi structured interviews.

Only 8 academics were selected for Semi structured interviews as they specifically requested changes to the program mapping matrix. This represented $57 \%$ of the staff responsible for $54 \%$ of the modules (8 of 14 academics and 15 of 28 modules)

Course outlines were collected for each module in order to determine the extent to which pervasive skills objectives and assessment criteria were specifically included. Course outlines for the 2016 academic year were scrutinized as these incorporated the changes envisaged by the focus group discussions.

Focus groups were held in each of the four disciplines (financial accounting, auditing, taxation and finance and ethics) during which strategies relating to how each discipline would accommodate these skills in their scaffolding and mapping were discussed.

All correspondence, primary and secondary data was stored electronically, although hard copies were used for ease of manuscript preparation. The project commenced with the researcher preparing a matrix based on the objectives (called competencies in the SAICA conceptual framework) SAICA (2015) with blank areas for academics to complete whether the objective was assessed and further requested details of how the objectives were achieved. Upon receipt of the completed matrices a consolidated program matrix was circulated, by e-mail, to all staff responsible for the core accounting modules in the program. This correspondence requested comment on the final matrix and information regarding their attitude to and methods used to address improving these skills. These responses together with responses from semi-structured interviews conducted to establish 
the rationale behind the modifications requested.

Focus groups based on the four subject disciplines allowed ensured that horizontal and vertical integration aspects were considered prior to the process of preparing course documentation in the form of formal course outlines for the 2016 academic year being prepared. Triangulation was the document scrutiny of module outlines ensuring evidence of the relationship between objectives, teaching methodology and assessment.

\section{Data Analysis}

Without exception all respondents felt that the pervasive skills were important to the extent that the most experienced academic in the department (incidentally also a previous staff partner in what was then one of the 'Big 5' audit firms) considers them more important than technical skills from a potential employers' perspective. The taxation lecturers felt that the open book assessment procedures further enhanced students' readiness for the work environment.

An unintended consequence of the project was a Departmental Graduate Attribute policy which married ideas from the institutional teaching and learning strategy and the graduate attribute policy of the Southern Cross University on the Gold Coast of Australia. The teaching and learning strategy sets the tone in the introduction of the new policy and is followed by definitions, a policy statement, procedures for embedding these skills across the programme and a fifth and concluding section being the program matrix. It has been submitted to the Senate through the faculty board and may influence institutional reforms in this area.

As the objective of this study is to adapt best international accounting curriculum design and revision practice to inform the development of pervasive skills in rural South African circumstances it will leave the evaluation of its efficacy to later longitudinal studies. Deficiencies noted in previous studies such as the recent synopsis of deficiencies and challenges facing professional accounting programs noted by Yap, Ryan and Yong (2014) can guide and inform the process.

The whole-of-program methodology for the inclusion of pervasive skills in an accounting curriculum envisages the steps outlined previously and the findings made at each stage are documented below. 


\section{Map the Courses Taught on the Programme}

This step of the process was made much simpler, as the SAICA-CF predetermines these. A number of additional items were identified during the interviews and focus groups which related not only to time management and organizational skills but included note taking, reading and comprehension challenges being absent in the typical entry level student. Efforts to address these omissions have been included through departmental initiatives and in cooperation with the intuition's writing centres (an academic development initiative) commencing in the current year.

A parallel process included mapping all the technical skills at the appropriate level and depth (i.e. a scaffolding process) which in common with other authors engendered a sense of departmental comradery. This process revealed not only gaps, which could be plugged with a capstone course, but duplications which freed time to focus on other activities. Academics were able to see a complete set of outcomes rather than a blinkered or silo view.

The alignment of program content, academic activities and assessments to support student success are not often considered by academics in higher education (Arafeh 2014). The mapping phase of the process ensures that skills or outcomes identified are specifically included in a process designed to obtain input and buy-in from those involved in program delivery are the foundation of best practice in curriculum assessment and development (Baht et al. 2004; Hill 2007; Arafeh 2015).

\section{Develop a Programme Map (Objectives, Teaching and Assessment)}

The preparation of an overall pervasive skills program map enabled an overview of whether particular skills are addressed and to some extent evaluates the depth to which they are covered. This map incorporated a number of changes, the efficacy of which will be evaluated in a future study.

There was little or no synchronization between when and what activities were performed. A good example was a group work project culminating in PowerPoint presentations being a second year requirement in two different modules presented in the first semester of the second year of the program. The solution was to amend one into a written group assignment focusing on word and excel skills with the final product being a business plan. 
Lifelong learning skills previously encouraged through use of the library, selected readings and non-academic research projects will in the future incorporate projects (e.g. presentation of business plans and listed company valuation exercises) aimed at communicating current developments in diverse fields to students.

Staff did attempt to align the objectives with teaching and assessment activities (Stivers et al. 2000; Sumison \& Goodfellow 2004) however course guides merely reveal how the final mark is calculated rather than detail (e.g. Rubrics for presentation and group work projects). The loop referred to by Robley, Whittle and Murdoch-Eaton (2000) is not articulate as envisaged and further encouragement is required.

In common with Stoner and Milner 2010 who tried to integrate employability skills within a first year accounting course it was similarly felt students struggle to manage their time and were unable to take responsibility for their learning. Lecturers felt that correspondingly to their peers in the Scottish study, students must be given time across the whole degree experience to develop these skills.

Cooperative learning which includes small group working together on projects will help in preparing students for the work environment and compliment tutorial groups which are larger and more formal (Cottell \& Mills 1992).

The literature does indicate that that there is no such thing as a final map as the document must be continually reworked (Tariq et al. 2004; Knight 2001; Wolf 2007) through formal and informal evaluation efforts. Inputs from all stakeholders must be considered at regular intervals in a formal mapping update process.

\section{Analyse the Depth to which Pervasive Skills are Being Taught}

All lecturers, whist recognising the importance of pervasive skills, were not prepared to sacrifice technical content. This was expected and is in common with national and international observations (Wood 2014). The compromise was to indicate a willingness to adapt teaching and assessing methodologies to satisfy as many of the requirements as possible. Each discipline however adopts a different approach which can be summarized as follows 
Including Pervasive Skills in an Accounting Curriculum

\begin{tabular}{|l|l|}
\hline Discipline & Methodology of incorporating pervasive skills \\
\hline $\begin{array}{l}\text { Financial } \\
\text { accounting }\end{array}$ & $\begin{array}{l}\text { Emphasize skills when opportunity arises and allocate } \\
\text { presentation marks in assessments. They are driven by } \\
\text { the technical requirements of the ITC (Initial Test of } \\
\text { Competency) }\end{array}$ \\
\hline Auditing & $\begin{array}{l}\text { Include a specific professional skills assignment which } \\
\text { is assessed. Their discipline also includes formal } \\
\text { teaching of professional and ethical conduct which is } \\
\text { assessed through the use of case studies. }\end{array}$ \\
\hline Taxation & $\begin{array}{l}\text { Lecturers perceive open book examinations and } \\
\text { practical case studies provide sufficient evidence of } \\
\text { outcomes assessment loop. }\end{array}$ \\
\hline $\begin{array}{l}\text { Finance } \\
\text { management } \\
\text { accounting }\end{array}$ & $\begin{array}{l}\text { This discipline adopted a similar approach to Maughn } \\
\text { 2012, and has used a capstone course incorporating a } \\
\text { shotgun type approach of including as many pervasive } \\
\text { skills as possible in the final year module. }\end{array}$ \\
\hline
\end{tabular}

That the technical components of an accounting program should be narrow and deep rather than broadly based was refuted by Albert and Sack (2000) who in chapter 5 of their report state that too little attention is paid to globalization, technology and ethics. These areas together with the dearth of group work identified by Naidoo et al. (2011) have been addressed in the SAICA-CF and incorporated into the curriculum.

All course outlines mention pervasive skills by name, although some still retain the cross-fields outcomes terminology due to the current format of the university outline template. Communication skills based on established professional norms are also detailed. Support courses in Ethics, Business and Law include assessment criteria for group and assignment work with the remaining disciplines leaving out detail with regard to assessment including only how the final mark would be determined.

\section{Consider Changes in Course Objectives, Teaching Activities and Teaching Methods}

Course outlines for the new academic year followed the institutional template 
that enforced uniformity previously absent from these documents. It was postulated during an interview that the accrediting authority (SAICA) may regard the rigid formats as limiting however the template is now seen by staff as minimum disclosure and additional information may be added to supplement the institutional requirements.

The requirement that academic staff should inform students explicitly about Graduate Attributes embedded in the modules at the commencement of a module was for the most part overlooked. Only eight of the 26 module guides referenced the pervasive skills to the SAICA-CF. In common with other studies emphasis is placed on the discipline rather than the non-technical specific skills with guidelines for mark plans being overlooked.

All staff interviewed and those present in the focus groups felt the exercise was worthwhile with specialist facilitation being beneficial rather than essential. There was overall consensus that feedback from stakeholders would inform the further review that would, of necessity, be undertaken.

\section{Conclusion}

The study concludes that the whole-of-program approach is an appropriate method for including pervasive skills in the accounting curriculum at rural South African Universities. In addition, the methodology encouraged staff to accept responsibility for inculcating pervasive skills, addressing the concerns of Barac and du Plessis (2014) and Strauss-Keevy (2014).

The lack of teacher training and development together with the preoccupation of preparing students for their professional examinations (emphasizing technical skills) will exert constraint on teaching efficiency (Wood \& Maistry 2014) thus regular assessment and review is essential. Meetings to review the process and update the curriculum must be performed at least bi-annually.

This paper recognizes that there are researched methodologies for curriculum review that include feedback from students, employers and other stakeholders (SAICA and the sponsors of the program). The extent to which documented outcomes are perceived to have been learned from the program must be assessed and reported (Yap et al. 2014). 


\section{References}

American Accounting Association 1986. Future Accounting Education: Preparing for the Expanding Profession (The Bedford Report). Special Report. Sarasota Florida: AAA.

American Institute of Certified Public Accountants (AICPA) 1998. CPA

Vision: Focus on the Future, s.l.: Available at: http://www.aicpa.org/ RESEARCH/CPAHORIZONS2025/CPAVISIONPROJECT/Pages/CPA

VisionProject.aspx. (Accessed on 05 October 2016.)

American Institute of Certified Public Accountants (AICPA) 2011. CPA

Horizons 2025 Final Report, S.L.: Available at: http://www.aicpa.org/

Research/CPAHorizons2025/DownloadableDocuments/cpa-horizonsreport-web.pdf. (Accessed on 05 October 2016.)

Arafeh S 2015. Curriculum Mapping in Higher Education: A Case Study and

Proposed Scope and Sequence Mapping Tool. Journal of Further and Higher Education 1-27.

Ashbaugh, H., K.M. Johnstone \& T.D. Warfield 2002. Outcome Assessment of a Wwriting-skill Improvement Initiative: Results and Methodological Implications. Issues in Accounting Education 17,2: 123-148.

Baht, D., C. Smith, S. Stein \& R. Swann 2004. Beyond Mapping and Embedding Graduate Attributes: Bringing Together Quality Assurance and Action Learning to Create a Validated and Living Curriculum. Higher Education Research And Development 23,3: 313-328.

Barac, K. \& L. du Plessis 2014. Teaching Pervasive Skills to South African Accounting Students. Southern African Business Review 18,1: 53-79.

Bester, M \& D Scholtz 2012. Mapping our Way to Coherence, Alignment and Responsiveness. South African Journal of Higher Education 26.2: 282299.

Boyce, G., S. Williams, A. Kelly \& H. Yee 2001. Fostering Deep and Elaborate Learning and Generic (Soft) Skill Development: The Strategic Use of Case Studies in Accounting Education. Accounting Education A10,1: 3760.

Bunney, D., E. Sharplin \& C. Howitt 2015. Generic Skills for Graduate Accountants: The Bigger Picture - A Social and Economic Imperative in the New Knowledge Economy. Higher Education Research \& Development 34,2: 256-269.

Bunney, D. \& L. Therry 2011. Employability Skills in the Master of Profes- 
sionnal Accounting: One School's Journey. In: Developing Student Skills for the Next Decade: Proceedings of the $20^{\text {th }}$ Teaching and Learning Forum, 1-2 February. Perth: Edith Cowan University.

Bunney, D. \& L. Therry 2013. A Collaborative and Consultative Approach to Embedding Employability Skills across the Curriculum. International Journal of Arts and Commerce 2,4: 103-115.

Bunney, D. \& L. Therry 2013. Employability Skills in the Master of Professional Accounting: One School's Journey. eCULTURE.

Chapple, M. \& H. Tolley 2000. Embedding Key Skills in a Traditional University. In Fallows, S. \& C. Steven (eds.): Integrating Key Skills in Higher Education: Employability, Transferable Skills and Learning for Life. London: Kogan Page.

De Lange, P., B. Jackling \& A.M. Gut 2006. Accounting Graduates' Perceptions of Skills Emphasis in Undergraduate Courses: An Investigation from Two Victorian Universities. Accounting and Finance 46: 365-386.

Deppe, L.A., E.O. Sonderegger, J.D. Stice, D.C. Clark \& G.F. Streuling 1991. Emerging Competencies for the Practice of Accountancy. Journal of Accounting Education 9: 257-290..

Dunne, E. 1995. Personal Transferable Skills: Final Report. Exeter: University of Exeter.

English, F.W. 1978. Quality Contrrol in Curriculum Development. Arlington VA: American Association of School Administrators.

English, L., H. Bonanno, T. Ihnatko, C. Webb \& J. Jones 1999. Learning through Writing in a First-year Accounting Course. Journal of Accounting Education 17, 221-254.

Harden, R.M. 2001. AMEE Guide no 21: Curriculum Mapping: A Tool for Transparent and Authentic Teaching and Learning. Medical Teacher 23,2:123-137.

Harden, R.M. 2001. Curriculum Mapping: A Tool for Authentic Teaching and Learning. Medical Teacher 23: 123-137.

Herring, H. \& J. Williams 2000. The Role of Objectives in Curriculum Development. Journal of Accounting Education 18,1: 1-14.

Hill, A. 2007. Continuous Curriculum Assessment and Improvement: A Case Study. In Wolf, P. \& J. Hughes (eds): Curriculum Development in Higher Education: Faculty-Driven Processes and Practices: New Directions for Teaching and Learning. San Francisco CA: Jossey-Bass. 
IAESB (International Accounting Education Standards Board) 2012. Professional Skills and General Education Standard (IES 3). New York: IFAC. Knight, P.T. 2001. Complexity and Curriculum: A Process Approach to Curriculum-Making. Teaching in Higher Education 6,3: 369-381.

Koch, E. \& M. Kriel 2005. An Argument for Integrating Language or Language related Skills in the Accounting Curriculum. South African Journal of Higher Education 19,3: 218-229.

Lakshmi, G. 2013. An Exploratory Study on Ccognitive Skills and Topics Focused in Learning Objectives of Finance Modules: A UK Perspective. Accounting Education.

Madiba, M. 2011. Curriculum Mapping as Inquiry in Higher Education. In Bitzer, E.M. \& M.M. Botha (eds.): Curriculum Inquiry in South African Higher Education: Some Scholarly Affirmations and Challenges. Stellenbosch: Sun Media.

Matthews, R., M. Jackson \& P. Brown 1990. Accounting for Higher Education: Report of the Review of the Accounting Discipline in Higher Education. Canberra: Australian Government.

Maughan, P. 2013. Launching a Capstone Course for Undergraduates Studying. Accounting Perspectives in Southern Africa 1,1: 15-21.

Mills, B.J. \& P.G.J. Cottell 1998. Cooperative Learning for Higher Education Faculty. Phoenix, AZ: American Council on Education and Oryx Press.

Naidoo, J., B. Jackling, B. Oliver \& M. Prokofieva 2011. Identifying the Employment Expectation - Performance Gaps of Early Career Accounting Graduates. Victoria University unpublished.

NCIHE (DEARING COMMITTEE) 1997. Higher Education in the Learning Society. Report 9: Higher Education and Regions. Norwich, HMSO: s.n. Noorderhaven, N.G. 2004. Hermeneutic Methodology and International Business Research. In Marschan-Piekkari, R. \& C. Welch (eds): Handbook of Qualitative Research Methods for International Business. Cheltenham, UK: Edward Elgar.

Power, M. 1991. Educating Accountants: Towards a Critical Ethnography. Accounting, Organizations and Society 16,4: 333-353.

Robley, W., S. Whittle \& D. Murdoch-Eaton 2005. Mapping Generic Skills Curricula: A Recommended Methodology. Further and Higher Education 29,3: 221-231.

Robley, W., S. Whittle \& D. Murdoch-Eaton 2005. Mapping Generic Skills Curricula: Outcomes and Discussion. Further and Higher Education 29,4: 
321-330.

SAICA (South African Institute of Chartered Accountants) 2008. Competency Framework: Competencies of a Chartered Accountant (SA), at EntryPoint to the Profession. Johannesburg: SAICA.

SAICA (South African Institute of Chartered Accountants) 2011. Competency Framework Detailed Guidance For Academic Programmes: Competencies of A CA(SA), at the Point of the Part I Examination. (Assessment of Core Technical Knowledge). $3^{\text {rd }}$ Edition. Bruma Lake, Johannesburg: SAICA.

South African Institute of Chartered Accountants 2014. Competency Framework Detailed Guidance for Academic Programmes: Competencies of A CA(SA) at the Point of the Part I Examination. (Assessment of Core Echnical Knowledge). Volume I. Bruma Lake, Johannesburg: SAICA.

Stivers G., J. Campbell \& H. Hermanson 2000. An Assessment Program for Accounting: Design, Implementation, and Reflection. Issues In Accounting Education 15,4: 553-581.

Stoner, G. \& M. Milner 2010. Embedding Generic Employability Skills in an Accounting Degree: Development and Impediments. Accounting Education 19,2: 123-138.

Strauss-Keevy, M. 2014. Education Programmes' Responsibilities Regarding Pervasive Skills. Journal of Economic and Financial Sciences 2:415.

Sumison, J. \& J. Goodfellow 2004. Identifying Generic Skills through Curriculum Mapping: A Critical Evaluation. Higher Education Research \& Development 23,3: 329-346.

Tariq, V.N., E.M. Scott, A.C. Cochrane, M. Lee \& L. Ryles 2004. Auditing and Mapping: Key Skills within University Curricula. Quality Assurance in Education 12,2: 70-81.

Van der Schyf, D.B. 2008. The Essence of a University and Scholarly Activity in Accounting, with Reference to a Department of Accounting at a South African University. Meditari Accountancy Research 16,1: 1 - 26.

Willcoxon, L., M. Wynder \& G.K. Laing 2010. A Whole-of-program Approach to the Development of Generic and Professional Skills in a University Accounting Program. Accounting Education 19,1-2: 65-91. Wolf, P. 2007. A Model for Facilitating Curriculum Development in Higher Education: A Faculty-Driven, Data-Informed, and Educational Developer-Supported Approach. New Directions for Teaching and Learning 
117: $15-20$.

Wood, N. \& S. Maistry 2014. Professional Accounting Associations' Influence on Higher Education Accounting Pedagogy. Alternation Special Edition 12: $198-239$.

Yap, C., S. Ryan \& J. Yong 2014. Challenges Facing Professional Accounting Education in a Commercialised Education Sector. Accounting Education: An International Journal 23,6: 562-581.

Zeff, S. 1979. Editorial. The Accounting Review 54,1, January: 226-238.

Mark Livingstone Faculty of Commerce, Administration and law University of Zululand, South Africa LivingstoneM@unizulu.ac.za

Sam Lubbe Milpark Business School Melville ext 2 Auckland Park Johannesburg Sam. Lubbe@gmail.com 